\title{
Picking the Right Arrow for the Target: Modelling the Economic Impact of Remittance on Agribusinesss Entreprenuership and Youth Employment in Sub-Saharan Africa
}

\author{
Gamel Abdul-Nasser Salifu ${ }^{1}$ \\ ${ }^{1}$ Department of Economics, School of Liberal Arts and Social Sciences, (SOLASS), Ghana Institute of Management \\ and Public Administration, Achimota, Accra, Ghana \\ Correspondence: Alhaji Gamel Abdul-Nasser Salifu, Lecturer, Department of Economics, School of Liberal Arts and \\ Social Sciences, Ghana Institute of Management and Public Administration, Achimota, Accra, Ghana. \\ Received: January 1, 2021 \\ Accepted: January 25, 2021 \\ Online Published: February 1, 2021 \\ doi:10.5430/bmr.v10n1p18 \\ URL: https://doi.org/10.5430/ bmr.v10n1p18
}

\begin{abstract}
The consequences of conflictual views on modelling the economic impact of remittances on agribusiness entrepreneurship and economic growth, has been present for a long time in the economic literature, albeit in a somewhat scattered way. This has attracted wide-spread criticism for agribusiness inititaives and its failure to address rural unemployment within the context of youth participation in the global food markets. This paper provides a summary of the global evidence published in the thematic area of international migration-remittance and sustainable development with emphasis on the financialisation impact of remittance on agribusiness entreprenuership and economic growth. The paper selectively reviews over 100 documented cases that offer insights into the methodological approaches for empirical modelling of remittance studies around the world. The paper bridges different stands of literature in economic and business management sciences and exemplifies the new complementaries between remittance, agribusiness and supply chain developments. Much as the paper advances no particular theory for modelling the economic impact of remittances on agribusiness entreprenuership and growth, it clearly offers insights into picking the appropriate methodological approaches for empirical estimation of the net effects of remittances on agribusiness entrepreneurship and rural youth employment in Africa, Asia and Latin America. The paper pinpoints ample evidence and brings a case for use of randomized experimentation approaches in Sub-Saharan Africa prone to the vagaries of weather- shocks and climate change. The paper further elaborates the nexus between remittance and contemporary development themes of poverty reduction and inequality, investment and savings, labour supply participation and economic growth. The experimental evidence reported around the globe showed that remittances have positive effects on poverty reduction but negative ramifications for labour supply, education, and economic growth. The analysis made a startling discovery which demonstrated that although, remittances reduced labour supply participation in developing economies; it significantly increased consumption of luxury goods in migrant households and made no positive contribution whatsoever to economic growth. This sorepoint courts new attention on resolution of the dilemma of remittance on economic welfare and advances an immediate redress of the emerging crises of methodological misuse in Development economics. Specifically the paper finds penalties with choice of methodological approaches for modelling the economic impacts of remitance on agribusiness entrepreneurship and economic welfare and advocated the inculcation of political economy perspectives in order to intergrate the multidimensionality of the complicated linkages of remittance to agribusiness entrepreneurship, rural youth employment and sustainable economic growth.
\end{abstract}

Keywords: Remittance, migration, poverty, finance, investments, agribusiness, entreprenuership, youth employment, economic growth

\section{Introduction}

To send or not to send, is the major question of the paradox of remittance to be answered by migrant workers with left-behind families in Africa, Asia and Latin America. Consequently, remittances are the intrafamilial money transfers made to remittance-receiving households for sustainable investment into agribusiness entrepreneurship and self-employment activities, leading to economic growth (Salifu, 2021; Acosta, 2020). Economic growth generated by remittance stimuli provides theoretical perspectives for empirical evaluation of the net effects of international 
migration on income redistribution in poor regions of the world. Hence, remittance serves as efective intermediaries for poverty reduction and sustainable economic growth in the developing world (Abebaw, Admassie, Kassa, \& Padoch, 2020; Antman, 2013; Adams, 2006). The crucial interjection of remittance in poverty alleviation and enhancement of economic welfare is well evidenced in the financial capitalization it provides for dynamic entreprise development culture in the sustainable promotion of investments into agribusiness entrepreneurship and youth employment (Anaman, 2018).

For these reasons, international remittances to African countries have commanded global attention in recent times than any other period in the last 50 years of development economics and international development work. It is estimated by the international monetary institutions that total remittances to Lower Middle-Income countries (LMIC) have totalled U.S $\$ 51$ Billion in 2020. This figure far exceeds the total official aid to Africa in both private debt and portfolio equity (World Bank, 2020). The statistics are further projected to incur an annual boost of $9.8 \%$ of donor aid to Sub-Saharan Africa where remittances constitute over $20 \%$ of Gross domestic Product (GDP).

Since the outbreak of the global pandemic, African economies have struggled with declining growth rates albeit improvements in the first quarter of 2019 from 2.3 percent in 2017 to 2.5 percent in 2018 (World Bank, 2019). The cascading effects of dwindling growth have created slugglish momentum in global economic trade with African economies experiencing the heightening impacts of shortfalls in demand for agricultural exports and increasing tariffs on exportation of primary commodities (Adhikari, 2017). While the demand for African commodities has declined in the face of globalization, the share of remittances to African countries has doubled (Cai et al., 2020). This has led to a flurry of studies on the economic impact of remittance on agribusiness entrepreneurship and economic growth in Africa, Asia and Latin America.

Accordingly, several economic policy papers have examined the impact of remittances on agribusiness development, poverty reduction, education, health, labour supply, investment and economic growth in all three different parts of the world. While these studies have confirmed a positive correlation between remittances and poverty reduction, others have found otherwise, with annual remittances declining with labour supply participation and economic growth in developing countries (Bossavie \& Denisova, 2018). These controversies have generated new debates on the ramifications of international remittances to the developing world. The need to re-evaluate the context within which remittances become an effective tool for agribusiness entrepreneurship and economic growth becomes imperative in the light of the aforementioned facts.

Consequently, the purpose of this paper is to review the documented evidence of the net effects of migration-remittance on agribusiness entrepreneurship and youth participation in the rural non-farm economy.The study sharpens focus on recent empirical, studies from 2000 to 2020 . There are two major reasons for this new focus. First, the literature on remittance and economic growth is too large to cover all periods. Secondly, in the review of recent studies, it is expected that a number of methodological adjustments would have improved the reliability of the estimation techniques for a vigorous analytical critique of migration- remittance research around the world.

The paper clarifies the role of remittances in sustainable economic growth by settling the controversies surrounding recent studies on the global impact of remittances on agribusiness entrepreneurship and rural youth employment. It also aims to demonstrate the importance of context in understanding the impact of remittances in Africa, Asia and Latin America. The overview of the economic impact of remittances on agribusiness formation is futher granted by the increasing lack of clarity in the local and regional debates on remittance contribution to economic growth and rural development. The dynamic impact of remittances on agribusiness entrepreneurship and rural welfare has not been clearly understood and articulated by national policy makers in Sub-Saharan Africa. Ideal-type reviews such as one proposed in this article can serve as useful devices for refocusing global attention on remittance contribution to agribusiness entreprenuership and youth unemployment in Africa.The methodological critique also provides a fundamental platform for re-assessing development policy initiatives on agribusiness entrepreneurship through promotion of targeted remittances to needy households in rural Northern Ghana and other parts of Africa. It also sharpens the local and international development perspectives on remittance impact on agribusiness development and job creation opportunities for jobless graduates in sub-saharan African countries such as Ghana, Nigeria and Mali.

The structure of this paper is as follows; it identifies the methodological gaps in modelling the impact of remittances on agribusiness development and the proposed solutions to bridging the identified methodological gaps. This is followed by a summary of the theorectical assumptions underpinning remittance research and the vital linkages of remittance to agribusiness development and rural employment. This is followed by discussion of the relationship between remittances and poverty reduction, education and health, investment and agribusiness entrepreneurship. The rest of this 
paper is devoted to the discussion of the impact of remittances on economic growth. This is concluded with summary of the vital outcomes of the review and suggested areas for further research.

The main objective of this review is to assemble the various theories and empirical works undertaken in the thematic area of remittances and economic growth. This paper contributes to the international literature by providing a synthesis of research works undertaken over the last twenty years and indicating gaps in the literature which may prompt new research works to advance the analysis of the economic impact of remittances on agribusiness entreprenuership and its linkages to economic welfare as an important policy tool for poverty reduction and development work around the world.

\section{Methodological Problems of Modelling Remittance Effects on Agribusiness Entreprenuership}

The empirical realities around the world have identified the major factors driving remittance, household expenditure and investments in agribusiness entrepreneurship and self-employment. These studies have utilized different range of methodological approaches for assessing the economic impact of international remittances on poverty thresholds, labour supply regimes, economic growth and microenterprise development (Marafa, May, \& Tenebe 2020; Guo, 2019; Alcaraz, Chiquiar, \& Salcedo, 2012; Amuedo-Dorantes \& Pozo, 2006a). Notwithstanding the significant contribution of these studies to enhancing our understanding of the global impact of remittances on economic welfare and agribusiness development, the conclusions drawn from the analysis of experimental data raises intricate questions about the methodological validity and soundness of the approaches used in modelling the empirical relevance of remittance to agribusiness entrepreneurship and household welfare. Consequently, four important methodological problems have been detected in the literature. These include; 1) Selection bias, 2) Simultaneity, 3) Reverse casaulity, 4) Omitted variables bias.

\subsection{Unobservability Bias}

Unobservability bias is a common methodological problem in studies focusing on global impact of international migration remittances on labour market allocations in the developing world. It is also prominent in empirical analysis of emigration effects on labour market outcomes and female force participation in the carribean countries (Asteriou \& Hall, 2015). The studies conclude that international migration exerts a negative influence on responsiveness of households to labour supply markets (Cooray, 2012; Dávalos, Karymshakov, Sulaimanova, \& Abdieva, 2017). This conclusion could be somewhat biased because the non-responsiveness of households to labour markets could be attributed to decisions concurrently made with other related household factors which has no direct relationship with migration (Demurger \& Li, 2013). For instance, household's decisions to sponsor the education of the brightest child abroad at the same time educating the not-so-bright child at home, could significantly influence household's responses to labour markets in the short-term due to convergence of household decisions creating a subtle problem of simultaneity.

The unobservability of the simultaneity of household decision-making would lead the researcher into drawing incomplete conclusions (Barham, \& Boucher, 2000). In the analysis of several studies it is noted that the variables which cause a decline in household livelihood outcomes of consumption, education and health also drive remittances and labour supply patterns (Cabegin, 2006; Duryea, Lopez-Cordova, \& Olmedo, 2005). Moreover, the characteristics which cause remittances, migration and labour supply to decline in the developing world are unobservable (Funkhouser, 2006). Furthermore, progressive households may choose to migrate and remit but it is hard to measure the ambition and progressiveness of the individual. These and other similar issues make it difficult to establish causality in migration and remittance studies which have implications for agribusiness entrepreneurship and business formation. In the light of this new limitation attributed to unobservability bias, the factors which cause households to produce migrants and to receive remittances for business entrepreneurship could be very difficult to explain using the methodological approaches sought in the above-mentioned studies.

\subsection{Reverse Causality}

The reverse causality methodological problem is quite prominent in studies on the dynamic impact of internal remittances on household expenditure, financial development, savings and poverty streams of sender households (Lenoel \& David, 2018; Maharjan, Bauer, \& Knerr, 2012). While it is reported in many new studies that a positive correlation exists between internal or local remittances and poverty reduction, it is still important to emphasise that the incidence and depth of poverty trajectories also exerted a catapulting effect on the share and frequency of annual or monthly remittances received by sender households of interest. Hence, the dynamic reverse causality is denoted in the reversality of remittances and poverty. In this regard, empirical studies which attempted to model the effect of remittances on poverty without a thorough consideration of the reverse casaulity between remittance and poverty 
variables certainly reached erroneous conclusions. A plethora of emerging studies on remittance effects on poverty reduction have consistently manifested this inherent challenge in the modelling approaches adopted to empirically test the associations of remittance outcomes to poverty reduction in Africa, Asia and the Bahamas.

\subsection{Selection Bias}

Selection bias tops the list of methodological problems encountered in quantitative modelling of the growing impact of remittances on agribusiness development (McKenzie, Gibson, \& Stillman, 2006; Massey \& Parrado, 1998). The empirical review showed that the methodological problem of selection bias was predominant in the studies which sought to substantively establish the magnitude of the impact of migration remittance on household welfare outcomes such as food security, health, education and agribusiness entrepreneurship (Malang \& Holzinger, 2020).

The selection bias problem might have risen from consistent failure of remittance studies to observe the strict codes of random selection procedures. The selection bias or selectivity problem was an overriding factor in sampling of migrants and remittance-recieving households. For instance if an international-migrant household received more remittances by virtue of its production of more educated migrants and income, then it was inappropriate to identify the factors influencing remittances-received by a simple comparison of the socio-economic characteristics of the migrants. If researcher overlooked the exogenous factors within the context of the analysis, then an inconclusive outcome was most likely to be reached.

In this particular scenario, if the researcher undertook positive selectivity of the respondents, then households with more educated migrants and income were more likely to receive more remmitance compared to those with little education and income. From this observation it was pretty accurate to suggest that the outcome of the study would be the reverse, had the researcher adopted a different measure, thus using negative selectivity sampling procedures in drawing the respondents of the study. This explains why the undertaking the first step of determining the direction and extent of selection bias is so crucial in modelling remittance effects on household welfare and agribusiness entrepreneurship in the developing world.

\subsection{Ommitted Variable Bias}

The omitted variable bias methodological error is very common in empirical studies dealing with remittance effects arising from household exposure to growing risk of seasonality and adverse environmental shocks (McKenzie \& Yang, 2010). In modelling the empirical studies of remittance outcomes on household welfare impacts, households exposure harsh weather conditions may be unobservable until a climate change event occurs (Ruiz \& Vargas-Silva, 2009). This unobservability would most likely goad the researcher on to omission of intensive weather-shock variables in the estimation of the net effects of remittance on household consumption and economic welfare (Salifu, 2021; Stillman, McKenzie, \& Gibson, 2006).

Many studies of economics and finance descent have shown this apparent methodological weaknesss. Consequently, the empirical models used have shown a consistent pattern of omission of important risk variables which were not perceived at the time of study, yet remain a major driver of resielience and capacity of a household to adapt to cyclical changes in food production systems. The evidence on sustainable livelihood frameworks indicate that successful coping strategies to risk and climate-change stresses leads to positive livelihood outcomes and externalities for the household whiles maladaptive strategies generate negative externalities and outcomes (Woodruff \& Zenteno, 2007).

The discussion of sustainability outcomes for household's proceeds from the assumption that households exposed to the severity of risks and shocks would most likely produce no international migrants and consequently receive no remittance cash flows. Therefore without the resolution of the methodological problem of omitted variable bias, important risk and shock factors which drive remittance outcomes for risk-averse households could be difficult to estimate. Much as the review points outs these omissions it does not reject the hypothesis of the practical challenge of researchers in sub-sahara Africa to gather quality reliable data on unobseved risk and shock factors. There are several reasons for panel data gathering challenges in rural Africa. First, farmers whether educated or uneducated rely on memory recall to provide information because of the apparent challenge of record keeping. The reliability of data depends on quality of memory. Ultimately, error attaches itself to any statistic which is estimated from the statistician's population and results gained from the analysis could be erroneous. Without a cost-route approach to data collection techniques, sampling error, concealment error, clerical error and human error could increase the potential for biased and erroneous conclusions (Moser \& Kalton, 1979; Anaman, 2018). The implication is that empirical studies could lead to misguided policy formulation or remain another case of shoddy scientific experimentation to be cited as irrelevant research. This is why several studies in rural Africa for instance cannot be replicated. Many policy implementors in the developing world have recently fretted about the quality of research and declared that 
three-quarters of empirical studies are bunk. This defeats the purpose of empirical estimation and the opportunity cost of stymied research could be hard to quantify in the long run for researchers and academics. The obligation to 'publish or perish' has come to rule academia and competition for jobs are cut-throat as freshly minted academics vie for top academic posts in universities and research institutes. However, given the methodological challenges raised in the discussion of remittance impact on welfare and economic growth, it is suprising to note that large swarthe of academic studies and policy conclusions have been produced in this subfield.

\section{Resolving the Methodological Problems of Modelling Remittance on Agribusiness Development}

Several analytical approaches have been proposed for addressing the methodological problems encountered in migration-remittance research (Yang, 2008; Kim, 2007; Adams; 2006; Gubert, 2002; Rodriguez, 1998). These include the 1) Randomised Experimentation Approach 2) Natural Experimentation Approach 3) Panel Data Approach 4) Counterfactual Methods 4). Mathematical Regression Models 5). Instrumental Variable Approaches.

\subsection{The Randomized Experimentation Approach}

The randomized experimentation approach, to resolving the methodological biases proceeds from the premise that the creation of an experiment in which a control group is invariably, compared to a non-control group, is necessary in the empirical modelling of international remittance effects on agribusiness formation (Giuliano, \& Ruiz-Arranz, 2009). A typical example in remittance research involves the sampling of respondents who wish to migrate internationally and have been refused visas due to lottery bias, as control versus actual migrants. Comparing the control group of aspiring migrants versus group of actual migrants helps to establish the factors which incentivize migration and remittances received. This improves the reliability and validity of the conclusions on international migration and remittance studies.Unfortunately the randomized experimentation approach is rarely deployed in remittance and financial inclusion studies in Sub-saharan Africa; A sore point in economic analysis of remittance impact on agribusiness development in Ghana, Nigeria, and the Muslim belt of West Africa (Burkina Faso, Senegal, Mali, and the Gambia).

\subsection{Natural Experimentation Approach}

The natural experimentation approach addresses the gap posed by the methodological problem of omitted variables due to unobservability of shock factors in the natural environment of households (McKenzie \& Yang, 2010). This approach essentially captures the exogenous shock variables from nature such as weather shocks in degradable agriculture or exchange rate variations that cause changes in the right-handside variables. For example Yang and Martinez (2006) use changes in exchange rates before and after the financial crises of Asian economies as exogenous shocks on migrant's incomes in order to model the impact of shocks on poverty reduction and agribusiness entrepreneurship in the Phillipines. The natural experimental approach is best deployed in regions of ruralAfrica where natural climatic shocks abound.

\subsection{Panel Data Approach}

The panel data eliminates the methodological problems which arise in modelling remittance outcomes in the developing world. This records repeated observations on the household over different periods within a time period (Osili, 2004). This approach circumvents the problem of unobservability of household characteristics not perceived by the researcher. This helps to resolve the problematic issues of endogeinity and omission biases common in cross-sectional surveys (Meraner, Pölling, \& Fingera, 2018). Unfortnately gathering panel data on migration and remittances is extremely expensive and rarely conducted. Few excellent panel data exist on rural African households; hence fewer studies have utilized this methodological approach. Of the 100 new articles reviewed only 5 percent of the studies employed panel data techniques to estimate the impact of migration-remittance on agribusiness entrepreneurship.

\subsection{Counterfactual Approach}

The use of counterfactual approaches as a methodological proposition revolves around the construction of a 'counterfactual situation' as a necessary step in the empirical estimation of the economic impacts of remittance on welfare status (Lokshin \& Glinskaya, 2009). This simulation allows the researcher to artificially assess what the situation would be like for a given household had a member not migrated. If the analysis is centred on a discussion of remittance and income for instance, it would be important to estimate the income of the migrant household by imputing the value of the migrant had he not diversified and stayed localized in the community. Where it is difficult to impute migrant income at home, propensity score matching technique could be used to establish these counterfactuals (Salifu, 2020). Propensity score matching awards points to households based on similarity characteristics of unobserved dynamics with non-migrant households (Matsuyama, 1992). This approach is often criticized for ignoring selection 
bias in the sampling procedures but its appropriateness lies in its proxy-uses to estimate migration and remittance effects on household welfare and agribusiness entreprenuership.

\subsection{Mathematical Regression Approach}

Mathematical regressions are a common solution to methodological problems in migration and remittance research. The approach is to regress the outcome of interest on a set of independent variables using ordinary Least Squares (OLS) (Calero, Bedi, \& Sparrow, 2009). This is usually supplemented with a sample selection procedure using for instance the two-stage Heckman model. The selection model is used to estimate the size and direction of the sample bias (Chami, Fullenkamp, \& Jahjah, 2005). The major problem with this approach is specifying the exogenous variable which causes a change in the variables of interest on the left-handside. But that is also a question of what type of study is conducted and outcome depends on the objectives of study and driving motivations for regression analysis.

\subsection{Instrumental Variable Approach}

The use of the instrumental variable methodological approach is based on the selection of an excellent variable that does not correlate with the outcome variable yet has a direct relationship with the explanatory variables of interest (Cox-Edwards \& Rodriguez-Oreggia, 2009). This is important as it eliminates, the biases associated with endogeneity and omission of the variable problems. The greatest challenge with this approach is in the identification of a good instrumental variable that satisfies the two preconditions for use. For example, in the analysis of the empirical relationship of remittances and poverty, assuming remittance is the explanatory variable and poverty, the outcome variable.

The challenge is to find that unique variable that is both correlated with remittances received by household head yet uncorrelated with poverty. In this case, the outcome could be tested by regressing on the instrument. However, establishing the exogeneity of the instrumental variable is one of the major challenges of using the instrumental variable approach in empirical modeling of household welfare impacts. Dary and Urstaz (2020) resolves this challenge in use of the instrumental variable multinomial approach to assess the impact of internal remittances on employment choices in rural Ghana. Employment choices were categorized as wage employment, self employment and domestic employment. They were then modelled based on conditional mixed process estimation techniques using farm employment as instrumental variable. The study found that remittances reduced participation in self-employment but increased participation in domestic employment.

\section{Theories of Agribusiness-Remittance: Altruism, Insurance and Investment.}

Several empirical studies have examined the impact of remittances on household welfare and agribusiness entreprenuership. However, it was Lucas and Stark (1985), who clearly identified the three major motives for remitting. The motivations were: (1) Altruism (2) Insurance and (3) Investment. New studies in rural Africa have also proposed a portpouri of reasons based on the combinative impacts of altruism, insurance and investment theories.

\subsection{Altrusim Theory of Remittance}

The motivational theory of altruism argues that the desire to help household members at home is the principal reason for remitting households of origin. Brown and Poirine (2005) support the assertion of altruism as the principal motive for remittance-sending behaviour of international migrants. In a study on the impact of international remittance on household welfare and agribusiness entreprenuership, the authors find that children were motivated by a sacred obligation to remit parents and guardians at home. The study tested a number of propositions derived from altruistic concepts using tobit regression model procedures to estmate the determinants of remittance-sending behaviour patterns of migrants. The study found an inverted U-shaped pattern between age of the migrant and decision to remit parents. The study argued that amount of remittances received correlated with future decision to return home or to stay abroad. The educational level of the migrant also correlated with remittances received by parents. Migrants who earned terminal degrees such as masters and doctorate degrees remitted more income to parents whiles those without educational background remitted less. The Authors do not use the instrumental variable approach to test the proposition of altruism hence conclusion could be biased.

\subsection{Insurance Theory of Remmittance}

Insurance theory of remittance seeks to test the empirical assumption that remittance is motivated by the desire to self-protect and secure family members against adverse risk and shocks. This desire is demonstrated in act and deed by formal ratification of an insurance contract to remit annually or monthly based on the obligations and terms of reference spelled out in the family contract. These formal or informal agreements to remit are reached by contract beneficiaries prior to international migration. This is a common phenomenon in Latin America. La Bariel et al. (2002), 
examines remittance patterns of Dominican migrants and remittance payments to parents. They point out that the decision to honour the terms of the contract is often driven by the sole desire to receive parent's bequests upon return to native countries.

The tobit regression model was used to assess patterns of remittances received by parents from children abroad. This approach is appropriate as the data captured households with migrants who had not remitted and otherwise treated as censored data. The Powell least censored estimator was also used to test for unobservability and deviation from the mean. The results showed that gender of remitter correlates with the amount of remittances received. Female migrants were driven by insurance motive to remit parents at old age compared to male migrants. Female migrants were also likely to increase remittance payments to parents when they sought medical attention. The evidence also showed that male migrants were more likely to remit less income to biological parents and more income to in-laws.

\subsection{Investment Theory of Remittance}

The Investment theory of remittances posits that the sole purpose of remittances is to invest in new areas of tremendous business potential such as agribusiness in rural Africa. Gubert (2000) investigated the investment drive among Malian migrant's and found that the principal reason for remittance was to invest in new business opportunities and also to revitalize ailing clan businesses. The study also found that the quantum of remittances received in Mali correlated with the occurrence of death in the family. This finding supports the investment theory of remittance. However, the methodological approach showed that selection bias was not adequately catered for hence conclusions were biased. The study also drew little attention to omitted variables issues which had a critical role to play in the determination of the outcome of international remittance in Mali.

The variables selected for this study were simply not adequate to explain the variations in volumes of remittances dispatched for re-investment opportunities in the region. This problem may have been influenced by the lack of reliable data to match the migrants with households of origin. Most of the studies on remittance and migration in rural Africa lack this matched data criteria. Hence, only a handful of studies have adopted the matched data criterion for empirical estimation of the impact of remittances on household welfare. For instance, Osili (2007), analyzed the motives for remittance and the impacts on savings using matched data on Nigerian migrants and remittance-receiving households to control for the possibility of omission variable bias in the modeling approach. The study found that savings dominated the reasons for international remittance. It also correlated with family land assets. In this study the problem of reverse causality bias was detected. The author used cross-sectional data to capture the causality but failed to clearly distinguish the positive correlation of previous investments received with current household income streams. This led to an erroneous conclusion that remittances positively correlated with household incomes.

\section{Financialisation of Remittance for Agribusiness Development}

Remittance as a tool for capitalization of agribusinesses has been well articulated by policy makers who assert that agribusiness is the engine of growth and the most effective tool for poverty reduction and food security in rural Africa (Ding \& Abdulai, 2020). In furtherance of this objective, African governments have continued to inject large sums of capital, costing billions of dollars into agribusiness entrepreneurship in concerted efforts to generate employment opportunities for jobless university graduates in Ghana, Nigeria and the Muslim belt of West Africa. However, investments efforts are thwarted by poor co-ordination and administration of agricultural activities within the commodity value-chains. The Market-oriented value-chains which promote agribusiness entrepreneurship are constrained by poor infrastructure, market fragmentation and price control effects in the developing world.

Remittance income as financial alternative to missing credits markets in Africa could empower small producers to meet the coordinated market chains and alliance requirements necessitated by the standardization of global food production (Durão et al., 2020). Increased remittances would increase money circulation in the economy as well as investment in capacity building of vital actors required for rural agribusiness success. Remittances generate substantial welfare gains for rural households lowering their poverty levels and increasing their access to private extension and business development services required to be intergrated into global food- market- economy (Forero-Cantor, Ribal, \& Sanjuán, 2020). Remittance plays a vital role in developing agribusinesses as it helps small farmers who do not have credit to launch new agribusiness entreprises. Remittance could also allow small producers to survive the medium term demands for substantial product differentiation in the agricultural sector (Amuedo-Dorantes \& Pozo, 2010).

Internal remittances would support the effective clustering of small producers to benefit from economies of scale. The clustering opportunities that remittances afford agribusiness entreprises would help small producers scale the market entry barriers through adoption of contract farming schemes in rural Africa. Contract farming has been identified as one of the most effective tools for vertical intergration of small farmers into global export market chains (Gershon, 
Ansah, Marfo, \& Donkoh, 2020). The changing dynamics of world agriculture makes, contract farming an effective option for rural households as public expenditure on input subsidies and credit programmes decline in Ghana, Nigeria and the Muslim belt of West Africa. Present day consumers in the developing world are demanding more than choice. They seek consistency and value, prompting a philophical change in what farmers can produce to what consumers really want to buy. In this instance, end-use-markets become the ultimate drivers of agricultural production and agribusiness.

\section{Remittance, Health and Education}

The varied empirical studies on the effect of remittances on health outcomes conclude that remittances decrease child mortality in poor households by virtue of its contribution to total household incomes. Remittances also improve the knowledge, attitude and skills of rural women to healthcare and safety measures. The evidence on the impact of remittances on educational status of migrant households is ambiguous (Antman, 2010a; Cooray, 2012; Brown \& Poirine, 2005). Whiles some studies argue that remittance increases school retention for adolescents in rural Africa, others indicate that international migration of parents increases school drop out rates. They find that international remittances discourage investment in education.

Uddin and Igbokwe (2020) examined the effect of international remittances on rural household welfare in Nigeria. They found that remittances smoothened consumption and improved women access to maternal healthcare. Duryea et al. (2005), studied the impact of remittances on infant mortality rates in the carribean countries. They employed the instrumental approach using two-stage least squares approach to derive the impact of remittances on mortality rates of children in Mexico. They concluded that remittances reduced infant mortality and improved consumption and maternal care at home.

The major challenge with the above-mentioned study is that it fails to identify the appropriate variables to instrument in the analysis. The variables selected for the instrumentation were revealed to be somewhat correlated with the outcome variable and quite biased. Hence the randomized approach which eliminates the bias by comparing the randomly-selected migrant goup (treatment), with the control group (non-treatment) non- migrant group, would have circumvented the methodological problem and established clarity in the analysis of the impact of remittances on migrant children's health and education.

\section{Remittance- Expenditure on Consumption, Investment and Business Formation}

Empirical studies show that a great percentage of total household remittance earnings are attributed to expenditure on three major items; 1) Consumption, 2) Investment and 3) Business formation (Acosta, 2007; Adams \& Cuecuecha, 2010b; Acharya \& Leon-Gonzalez, 2014). It is argued that the contribution of remittance to local economic growth depends on the expenditure incurred by households. Studies find that remittances invested in housing, jewellery and lands have limited impact on economic growth compared to expenditure on investments, business formation and rural enterprise development. This is because expenditure on investment and rural entreprises are seen as part of the broader process of the structural transformation of rural economies (Salifu, 2019).

The positive impacts of remittance-expenditure on investment through rural entreprise development are well articulated in development literature. For instance, Uddin et.al (2020) studied the impact of remittance on investments and rural enterprise development using panel data from 1975 to 2017.The study simultaneously employed the Granger-causality and Dumistrescu Hurlin Causality tests to estimate the impact of remittances on investments and entreprise development in five Asian countries. They found that remittances had a positive bearing on local investments and significantly stimulated micro-entreprise development in Bangladesh.

Adam and Ceuceucha (2010a) analysed remittance effects on entrepreneurial activities undertaken by households. The study employed the instrumental variable approach using the two-stage Heckman model to derive the relationship between remittances and entrepreneurial businesses. They find that household invest remittances on business enterprise growth as opposed to consumption smoothening. Yang (2008) uses the natural experiment approach to derive a positive linkage between share of international remittances received and rural entreprise development in the phillipines.

The empirical studies in developing countries indicate that large proportion of remittance incomes are disbursed on housing and land acquisition ventures. Osili (2004) investigated the impact of remittances on housing in Nigeria using the probit model. The study concluded that households invested remittances in housing and land acquisition as opposed to investment in entrepreneurial development.

Amuedo-Dorantes and Pablo (2004a), employed the probit model to assess the impact of remittances on business development. The study found that international remittances increased wage incomes of householders and decreased 
the need to invest in business formation. The conclusion reached by the study could be biased because the methodology used failed to account for selection bias in the sampling of migrant households. This challenge was addressed by the work of Woodruff and Zenteno (2007) on remittance impact on business formation in Latin America. The study employed the instrumental variable approach to estimate the impact of remittances on business growth. They found that remittances provided sufficient start-up capital for small business growth and expansion in Mexico. They concluded that a large share of agribusinesses was financed by remittance capital portfolios.

\section{Remittances, Labour Supply and Youth Participation in Rural Non-farm Economy.}

The evidence on remittance and labour supply points to two major effects on household participation in the rural non-farm economy. First, it allows households to circumvent the liquidity constraints inherent in the development of business enterprises in the rural areas constantly subjected to cyclical effects of agricultural production. Second, receipt of international remittances detains larbour force participation in agribusiness development by increasing wage income of households as empirical studies find that migration and remittances decrease household labour supply and participation in farm sector employment.

Acosta (2020) estimated migration effect on labour allocation using panel data from El-savadour. The study finds that migration generates only minor effets on labour allocation in South America. He concluded that migration has no effect on off-farm labour allocation and that remittances tend to decrease time allocated for off-farm activities with no effect on self-employment. Although, Acosta (2020) controls for selection bias and takes into consideration unbiased unobserved household heterogeneity by use of panel data, the study has one major weakness. It fails to account for the high differences in remittances and migration within the same household at certain periods of time.

Investigating the effect of remittances on household labour supply, Kim (2007), finds that in Jamaica, labour force participation decreases as international migration and remittances increases. The study employed panel data available on Jamaican household national surveys from 1995 -2002 to examine the fixed regression effects of current remittances on labour force particpication. International remittance was found to be a negative driver of household labour participation in small businesses. Households receiving international remittances were also more likely to be earning salaried wages from full-time jobs. This reduced the urgency to start small businesses, which was considered an extremely time-consuming entreprise for full-time workers.

The findings of Kim (2007), concur with Funkhouesor (2006), which confirms that labour force participation declined with quantum of international remittances received. Funkhouser (2006) also used panel data to estimate the fixed effects of international migration and remittances on household labour participation in Nicaragua. He concluded that international migrant households reduced their working hours as remittance income increased. Labour force participation in agribusinesses declined as share of remittance wages increased over time.

Although the studies address the relationship between remittance and labour supply, they fail to control for selection bias in migration and remittance studies and conclusions could be somewhat biased, as new evidence proved the contrary thus showed that international remittances stimulated the formation of small business entreprises for women in the Phillipines. Cabegin (2006) uses a probit regressin model to estimate the effect of international migration and remittances on household labour markets. The study found that migration had tremendous impact on spousal business formation. While women in non-migrant households worked full-time jobs, migrant spouses devoted more time to small business development in Phillipines. The author also concluded that gender had differentiated impacts on household labour participation.

While several studies conclude that remittances reduce household labour market participation, a study by Cox-Edwards and Rodriguez-Orregia (2009) comes to a different point. They used propensity score matching method to estimate the effect of remittances on migrant households in Mexico. They conclude that regular international remittances of the household head had no significant effect on labour participation of other members of the household. This finding is consistent with the idea that migrant workers remit to make up for lost household incomes due to emigration.

The propensity score matching technique first estimates the probability of migrant household participation in labour markets and then matching each international migrant to non-migrants with similar predicted probablities of migration. Although this approach is impeccable in comparing observed characteristics of houesholds, the technique fails to address the problem of selection bias and could influence the outcome of the results. For this reason the instrumental variable approach, which allows for correction of bias, could be an effective methodology for estimating the impact of migration remittances on household labour supply markets in rural Africa. 


\section{Remittances and Economic Growth.}

The impact of remittances on economic growth is well examined in economic literature albeit mixed findings and conclusions. While it is evident that share of remittances received contributes to household welfare consumption patterns and agribusiness entreprise development in the developing world, major new studies settles on the contrary. They posit that international remittance reduces sustainable economic growth (P. O. W. Adjei, J. O. Adjei, \& Serbeh, 2020). These ambiguous findings do not derail the evidence of remittances on GDP growth and unemployment but clearly outline the multidimensionality of remittance. It reveals the dynamic linkages of remittance to economic growth through new pathways. This has implication for migration-remittance research. The complicated patterns of remittance and economic growth are not exhausted with one-dimensional causative analysis of the impact of remittance on economic growth. Hence, a political economy approach which calls for more intergration and disentangling of the inter-woven linkages, sets pace for reaching new dimensions in migration- remittance research. For instance, remittance studies reviewed have not fully captured the direct impact of human capital development on economic growth.

In a recent study of the impact of remittances on economic growth, John, Orok, and Udoka (2020), find that remittance improves economic growth. In a more determined analysis of Oteng-Abayie, Awuni and Adjie (2020), they estimate the impact of remittance on GDP growth using granger causality test to explore the direction of causality. The authors used ARDL annual data from 1970 to 2016 to test for causality. They find that remittances had a negative effect on economic growth in Ghana. They concluded that for remittance to improve economic growth financial institutions would need to redirect and channel remittances away from consumption into savings and investment avenues. In an earlier study in Ghana, Antwi and Koranteng (2017) examined the effect of remittance flows on economic growth using the vector error correction model (VECM) and the Granger-causality test technique using data from (1990 to 2014). The challenge with this study was that the VECM technique it utilized created a methodological problem of model over-fitting leading to inconsistent estimation of the parameters driving remittance effect on economic growth in Ghana.

In a panel study of the impact of international remittances on the economic growth of 120 countries from all continents using fixed regression models, Chami et al. (2005), find that international remittances had a negative impact on per capita GDP growth. Economic growh tended to decline with share of international remittances received. The findings of Chami et al. (2005), questions the validity of the theory which denotes remittance income as crucial capital for economic growth without excpetion. Nonetheless, researchers argue that remittance income serves as compensatory allowance for poor developing countries.

The pestimistic findings of Chami et al. (2005) are contradicted by the findings of Guiliano and Ruiz-Arranz (2009) which conclude that remittances promote and stimulate economic growth in developing countries. Accordingly, remittances served as alternative sources of income for financially-constrained countries. Remittances substituted finances for development in countries struggling with missing credit markets. The authors arrived at these conclusions using cross-country data sets from 1975 to 2002 to analyse the effect of remittance on economic growth.

Lopez et al. (2007), reconciles the different positions by arguing further that the negative impact of international remittances on economic growth is felt by the devaluation of local tradable goods through a significant appreciation of exchange rates in domestic markets. The authors use panel data sets from 1990 to 2003 to assess the impact of remittances on exchange rates in ten Latin American countries. The study controls for endogeneity and reverse causality through instrumentation of the exogenous linkages of remitances to excahneg rates analysis. While these Latin American studies arrive at similar conclusions, the effect of remittances on exchange rate appreciation in India is positive. Rajan and Subraimanian (2005) use panel data sets from 33 countries to estimate the effect of remittances on exchange rates. They find that remittance does not depreciate domestic competitiveness; rather it stimulates external competitiveness which spurs economic growth.

\section{Conclusions and Recommendations}

This paper provides a summary of the theoretical concepts of migration remittance and its impacts on agribusiness development and economic growth based on an extensive review of 100 recent works in top tier economic journals compiled from all continents of the world. Several findings have been identified by this review which raises important questions, issues and gaps for further research. Firstly, because of the many methodogical problems confronting the analysis of the impact of remittances on agribusiness development and economic growthe in rural Africa, the randomized approach has been found to be most reliable for the analysis of the impact of remittances on agribusiness and economic growth. Unfortunately many studies reviewed in sub-saharan Africa had not adopted the randomized methodological procedures in the analysis. Secondly, the best approaches to solving the methodological challenges of 
agribusiness-remittance research were suggested. The natural experimentation approach, which uses an exogenous shock from nature as a basis for studies was suggested as a best technique for analysis in sub-saharan Africa. This would require the development and use of panel data in rural Africa where natural shocks abound. Panel data is excellent for remittance research as it captures the hetergenous datasets on original household's before and after shocks. Since panel data in Africa are rare, it seems unlikely that the natural experiment approach would become dominant in studies. Thirdly, the instrumental variable approach was also found to be excellent as it caters for selecton bias which arises from endogeneity and omitted variable problems. This approach would not be likely used in remittance studies in developing countries because of the difficulty in identification of good instrumental variables for the analysis. Fourthly, there is a consensus in the economic literature that international remittance leads to poverty reduction in the developing world. The studies also show that remittances reduce child mortality. International migration and remittances reduce labour supply participation because migrant households substitute increased income for consumption of luxury goods. Five and finally, this review shows that more work is needed to resolve the controversies on the impact of remittances on education and economic growth. While studies find that remittances increase child retention in schools, other studies find that international remittances reduce school attendance for teenagers. With respect to macroeconomc growth, studies find that remittances have negative impact on economic growth whiles other find the reverse. The differences arise from the methodological differences in the analysis. More importantly, work is required in the political economy differentiated-unity approach which accounts for the adaptive multidimensionality of the complicated linkages of remittance to agribusiness entrepreneurship and rural economic growth.

\section{References}

Abebaw, D., Admassie, A., Kassa, H., \& Padoch, C. (2020). Can rural outmigration improve household food security?. Empirical evidence from Ethiopia. World Development, 129, 104879. https://doi.org/10.1016/j.worlddev.2020.104879

Acharya, C. P., \& Leon-Gonzalez, R. (2014). How Do Migration and Remittances Affect Human Capital Investment? The Effects of Relaxing Information and Liquidity Constraints. Journal of Development Studies, 50(3), 444-460. https://doi.org/10.1080/00220388.2013.866224

Acosta, P. (2007). Entrepreneurship, labor markets and international remittances: evidence from El Salvador. In C. Ozden and M. Schiff (Eds.), International Migration, Economic Development and Policy (pp. 141-160). Washington, DC: World Bank.

Acosta, P., Calderon, C., Fajnzylber, P., \& Lopez, H. (2008). What is the impact of international remittances on poverty and inequality in Latin America? World Development, 36(1), 89-114. https://doi.org/10.1016/j.worlddev.2007.02.016

Adams, Jr., R. (2006). Remittances and poverty in Ghana. World Bank Policy Research Working Paper 3838. World Bank, Washington, DC. https://doi.org/10.1596/1813-9450-3838

Adams, Jr., R., \& Cuecuecha, A. (2010b) Remittances, household expenditure and investment in Guatemala. World Development, 38(11), 1626-1641. https://doi.org/10.1016/j.worlddev.2010.03.003

Adams, Jr., R., \& Page, J. (2005). Do international migration and remittances reduce poverty in developing countries? World Development, 33(10), 1645-1669. https://doi.org/10.1016/j.worlddev.2005.05.004

Adhikari, N. (2017). Linkage between Labor Migration, Remittance and Self Employed Business Activities in Nepal. International Journal of Entrepreneurship and Economic Issues, 1, 43-55. https://doi.org/10.32674/ijeei.v1i0.5

Adjei, P. O. W., Adjei, J. O., \& Serbeh R. (2020). Looking Beyond Cash Transfers for Optimizing Poverty Reduction and Livelihood Sustainability in Rural Ghana: Comparative Analysis of Two SocialPolicy Interventions Against Poverty. Poverty and Public Policy, 12(1), 84-111. https://doi.org/10.1002/pop4.270

Ahmed, A., \& Gasparatos, A. (2020). Multi-dimensional energy poverty patterns around industrial crop projects in Ghana: Enhancing the energy poverty alleviation potential of rural development strategies. Energy Policy, 137, 111123. https://doi.org/10.1016/j.enpol.2019.111123

Alcaraz, C., Chiquiar, D., \& Salcedo, A. (2012). Remittances, Schooling, and Child Labor in Mexico. Journal of Development Economics, 97(1), 156-65. https://doi.org/10.1016/j.jdeveco.2010.11.004

Amemiya, T. (1984). Tobit Models: A Survey. Journal of Econometrics, 24(1-2), 3-61. https://doi.org/10.1016/0304-4076(84)90074-5 
Amuedo-Dorantes, C., \& Pozo, S. (2004). Workers' remittances and the real exchange rate: a paradox of gifts. World Development, 32(8), 1407-1417. https://doi.org/10.1016/j.worlddev.2004.02.004

Amuedo-Dorantes, C., \& Pozo, S. (2006a). Migration, remittances and male and female employment patterns. American Economic Review, 96(2), 222-226. https://doi.org/10.1257/000282806777211946

Amuedo-Dorantes, C., \& Pozo, S. (2006b) Remittance receipt and business ownership in the Dominican Republic. World Economy, 29(7), 939-956. https://doi.org/10.1111/j.1467-9701.2006.00830.x

Amuedo-Dorantes, C., \& Pozo, S. (2010) Accounting for remittance and migration effects on children's schooling. World Development, 38(12), 1747-1759. https://doi.org/10.1016/j.worlddev.2010.05.008

Anaman, K. A. (2018). Economic Shocks and Growth in the Post-Independence Period, 1957 to 2017. Accra: Institute of Fiscal Studies.

Antman, F. M. (2010a). Adult Child Migration and the Health of Elderly Parents Left Behind in Mexico. American Economic Review, 100(2), 205-08. https://doi.org/10.1257/aer.100.2.205

Antman, F. M. (2013). The Impact of Migration on Family Left Behind. In A. F. Constant and K. F. Zimmermann, Eds., International Handbook on the Economics of Migration (pp. 293-308). Northampton, MA: Edward Elgar. https://doi.org/10.4337/9781782546078.00025

Asteriou, D., \& Hall, S. G. (2015). Applied econometrics (3rd ed., p. 345). Macmillan International Higher Education.

Bellemare, M. F., \& Wichman, C. J. (2019). Elasticities and the Inverse Hyperbolic Sine Transformation. Oxford Bulletin of Economics and Statistics. https://doi.org/10.1111/obes.12325

Binzel, C., \& Assaad, R. (2011). Egyptian Men Working Abroad: Labour Supply Responses by the Women Left Behind. Labour Economics, 18, S98-S114. https://doi.org/10.1016/j.labeco.2011.03.002

Bossavie, L., \& Denisova, A. (2018). Youth Labor Migration in Nepal. Jobs Working Paper Issue No. 13. Washington, DC: World Bank. https://doi.org/10.1596/29682

Bellon, M. R., Kotu, B. H., Azzarri, C., \& Caracciolo, F. (2020). To diversify or not to diversify, that is the question. Pursuing agricultural development for smallholder farmers in marginal areas of Ghana. World Development, 12, 104682. https://doi.org/10.1016/j.worlddev.2019.104682

Cai, J., Ma, E., Lin, J. et al. (2020). Exploring global food security pattern from the perspective of spatio-temporal evolution. J. Geogr. Sci., 30, 179-196. https://doi.org/10.1007/s11442-020-1722-y

Castro-Arce, K., \& Vanclay, F. (2020). Transformative social innovation for sustainable rural development: An analytical framework to assist community-based initiatives. Journal of Rural Studies, 74, 45-54. https://doi.org/10.1016/j.jrurstud.2019.11.010

Chamberlina, J., \& Jayne, T. S. (2020). Does farm structure affect rural household incomes? Evidencefrom Tanzania. Food Policy, 90, 101805. https://doi.org/10.1016/j.foodpol.2019.101805

Cooray, A. (2012). The impact of migrant remittances on economic growth: evidence from South Asia. Review of International Economics, 20(5), 985-998. https://doi.org/10.1111/roie.12008

Dapilah, F., Nielsen, J. O., \& Friis, C. (2020). The role of social networks in building adaptive capacity and resilience to climate change: a case study from northern Ghana. Journal of Climate and Development, 12(1), 42-56. https://doi.org/10.1080/17565529.2019.1596063

Dávalos, J., Karymshakov, K., Sulaimanova, B., \& Abdieva, R. (2017). Remittances and Labor Supply of the Left-Behind Youth: Evidence from Kyrgyzstan. Asian and Pacific Migration Journal, 26(3), 352-380. https://doi.org/10.1177/0117196817729190

Demurger, S., \& Li, S. (2013). Migration, Remittances, and Rural Employment Patterns: Evidence from China. In C. Giulietti, K. Tatsiramos, \& K. F. Zimmermann, E, (Eds.), Labor Market Issues in China (Research in Labor Economics (Vol. 37, 31-63). United Kingdom: Emerald Group Publishing Limited. https://doi.org/10.1108/S0147-9121(2013)0000037006

Barham, B., \& Boucher, S. (1998). Migration, remittances and inequality: estimating the net effects of migration on income distribution. Journal of Development Economics, 55(3), 307-331. https://doi.org/10.1016/S0304-3878(98)90038-4 
Brown, R., \& Poirine, B. (2005) .A model of migrants' remittances with human capital investment and intrafamilial transfers. International Migration Review, 39(2), 407-438. https://doi.org/10.1111/j.1747-7379.2005.tb00272.x

Cabegin, E. (2006). The effect of Filipino overseas migration on the non-migrant spouse's market participation and labor supply behavior. Institute for Study of Labor (IZA) Discussion Paper 2240, Bonn, Germany.

Calero, C, Bedi, A., \& Sparrow, R. (2009). Remittances, liquidity constraints and human capital investments in Ecuador. World Development, 37(6), 1143-1154. https://doi.org/10.1016/j.worlddev.2008.10.006

Chami, R., Fullenkamp, C., \& Jahjah, S. (2005). Are immigrant remittance flows a source of capital for development? IMF Staff Paper 52, 1, International Monetary Fund, Washington, DC.

Cox-Edwards, A., \& Rodriguez-Oreggia, E. (2009). Remittances and labor force participation in Mexico: an analysis using propensity score matching. World Development, 37(5), 1004-1014. https://doi.org/10.1016/j.worlddev.2008.09.010

Cox-Edwards, A., \& Ureta, M. (2003) International migration, remittances and schooling: evidence from El Salvador. Journal of Development Economics, 72(2), 429-461. https://doi.org/10.1016/S0304-3878(03)00115-9

Durão, S., Visser, M., Kredo, T. et al. (2020). Assessing the completeness and comparability of outcomes in systematic reviews addressing food security: protocol for a methodological study. Syst. Rev., 9, 9. https://doi.org/10.1186/s13643-019-1268-1

Duryea, S., Lopez-Cordova, E., \& Olmedo, A. (2005). Migrant remittances and infant mortality: evidence from Mexico. Unpublished draft manuscript, Inter-American Development Bank, Washington, DC.

Forero-Cantor, G., Ribal, J., \& Sanjuán N. (2020). Measuring regional differences in food security from access and stability dimensions: A methodological proposal based on elasticities. Agric. Econ. - Czech, 66, 112-119. https://doi.org/10.17221/97/2019-AGRICECON

Funkhouser, E. (2006) .The effect of emigration on the labor market outcomes of sender households: a longitudinal approach using data from Nicaragua. Well-Being and Social Policy, 2(2), 5-25.

Guo, Z. Y. (2019). Empirical performance of GARCH models with heavy-tailed innovations. Bulletin ofEconomic Research, 71(3), 359-387. https://doi.org/10.1111/boer.12186

Giuliano, P., \& Ruiz-Arranz, M. (2009). Remittances, financial development and growth. Journal of Development Economics, 90(1), 144-152. https://doi.org/10.1016/j.jdeveco.2008.10.005

Gubert, F. (2002). Do migrants insure those who stay behind? Evidence from the Kayes area Western Mali). Oxford Development Studies, 30(3), 267-287. https://doi.org/10.1080/1360081022000012699

Hildebrandt, N., \& McKenzie, D. (2005) .The effects of migration on child health in Mexico. Economia, 6(1), 257-289. https://doi.org/10.1596/1813-9450-3573

Kim, N. (2007). The impact of remittances on labor supply: the case of Jamaica. World Bank Policy Research Working Paper 4120, World Bank, Washington, DC. https://doi.org/10.1596/1813-9450-4120

Kirk, A., Kilic, T., \& Carletto, C., (2018). Composition of Household Income and Child Nutrition Outcomes Evidence from Uganda. World Development, 109, 452-469. https://doi.org/10.1016/j.worlddev.2017.03.023

Laborde, D., Martin, W., \& Vos, R. (2020). Poverty and food insecurity could grow dramatically as COVID-19 spreads. Blog published by the International Food Policy Research Institute (IFPRI). https://doi.org/10.2499/p15738coll2.133762_02

Lenoel, A., \& David, A. (2018). Leaving Work Behind? The Impact of Emigration on Female Labor Force Participation in Morocco. International Migration Review, 1-32. https://doi.org/10.1177/0197918318768553

Lokshin, M., \& Glinskaya, E. (2009). The Effect of Male Migration on Employment Patterns of Women in Nepal. The World Bank Economic Review, 23(3), 481-507. https://doi.org/10.1093/wber/lhp011

Lokshin, M., Bontch-Osmolovski, M., \& Glinskaya, E. (2010). Work-Related Migration and Poverty Reduction in Nepal. Review of Development Economics, 14(2), 323-332. https://doi.org/10.1111/j.1467-9361.2010.00555.x

Lucas, R. E., \& Stark, O. (1985). Motivations to Remit: Evidence from Botswana. Journal of Political Economy, 93(5), 901-918. https://doi.org/10.1086/261341

Malang, T., \& Holzinger, K. (2020). The political economy of differentiated integration: The case of common agricultural policy. The Review of International Organizations. https://doi.org/10.1007/s11558-020-09384-z 
Marafa L., May J., \& Tenebe, V. A. (2020). Upscaling Agriculture and Food Security in Africa in Pursuit of the SDGs: What Role Does China Play?. In Ramutsindela M., Mickler D. (Eds.), Africa and the Sustainable Development Goals. Sustainable Development Goals Series. Springer, Cham. https://doi.org/10.1007/978-3-030-14857-7_16

Maharjan, A., Bauer, S., \& Knerr, B. (2012). International Migration, Remittances and Subsistence Farming: Evidence from Nepal. International Migration, 51. https://doi.org/10.1111/j.1468-2435.2012.00767.x

Massey, D. S., \& Parrado, E. A. (1998). International Migration and Business Formation in Mexico. Social Science Quarterly, 79.

Matsuyama, K. (1992). Agricultural Productivity, Comparative Advantage, and Economic Growth. Journal of Economic Theory, 58(2), 317-334. https://doi.org/10.1016/0022-0531(92)90057-O

Massey, D., \& Parrado, E. (1998) International migration and business formation in Mexico. Social Science Quarterly, 79(1), 1-20.

Meraner, M., Pölling, B., \& Fingera, R. (2018). Data on farm diversification decisions and farmers' risk preferences in the Ruhr Metropolitan region (Germany). Data in Brief, 18, 9-12. https://doi.org/10.1016/j.dib.2018.03.008

McKenzie, D., \& Rapoport, H. (2006). Can migration reduce educational attainment? Evidence from Mexico. World Bank Policy Research Working Paper 3952, World Bank, Washington, DC. https://doi.org/10.1596/1813-9450-3952

McKenzie, D., \& Yang, D. (2010). Experimental approaches in migration studies. World Bank Policy Research Working Paper 5395, World Bank, Washington, DC. https://doi.org/10.1596/1813-9450-5395

McKenzie, D., Gibson, J., \& Stillman, S. (2006). How important is selection? Experimental versus nonexperimental measures of the income gains from migration. World Bank Policy Research Working Paper 3906, World Bank, Washington, DC. https://doi.org/10.1596/1813-9450-3906

Mulwa, C. K., \& Visser, M. (2020). Farm diversification as an adaptation strategy to climatic shocks and implications for food security in northern Namibia. World Development, 129, 104906. https://doi.org/10.1016/j.worlddev.2020.104906

Moser, C. A., \& Kalton, D. W. (1979). Survey Methods in Social Investigation. Heinemann Education Books. London

Nakajima, M., Otsuka K., \& Yamano, T (2018). Jobs Off the Farm: Wealth, Human Capital, and Social Group in Rural Eastern India. Journal of Development studies, 54(1), 111-132. https://doi.org/10.1080/00220388.2017.1283017

Narayanan, S., (2020). Food and agriculture during a pandemic: Managing the consequences. Blog published by Ideas for India

Osili, U. (2004). Migrants and housing investments: theory and evidence from Nigeria. Economic Development and Cultural Change, 52(4), 821-849. https://doi.org/10.1086/420903

Osili, U. (2007). Remittances and savings from international migration: theory and evidence using a matched sample. Journal of Development Economics, 83(2), 446-465. https://doi.org/10.1016/j.jdeveco.2006.06.003

Rajan, R., \& Subramanian, A. (2005). What undermines aid's impact on growth? National Bureau of Economic Research Paper 11657, National Bureau of Economic Research, Cambridge, MA. https://doi.org/10.3386/w11657

Rodriguez, E. (1998). International migration and income distribution in the Philippines. Economic Development and Cultural Change, 46(2), 329-350. https://doi.org/10.1086/452341

Ruiz, I., \& Vargas-Silva, C. (2009). To send or not to send: that is the question. A review of the literature on workers' remittances. Journal of Business Strategies, 26(1), 73-98. Social Science Research.

Salifu, G. A. N. (2021). The Proof of Economic Welfare is in the Eating of Nutritious diets by resource-poor; A Political Economy Analysis of the International Evidence of Dietary Consumption in Rural Africa. International Journal of Business Administration, 12(1), 10-34.

Salifu, G. A. N. (2020). Political Economy Analysis of Income Diversification Activities of Rural Households and Food Security: A Case Study of Yendi and Nanumba North Districts of the Northern Region of Ghana 
(Unpublished Doctoral thesis, Department of Agricultural Economics and Agribusiness, University of Ghana). https://doi.org/10.11114/aef.v6i5.4405

Salifu, G. A. N., \& Anaman, K. A., (2019a). Political Economy Analysis of Income diversification of Rural Households in the Northern Region of Ghana. Applied Economics and Finance, 6(5), 10-34. https://doi.org/10.11114/aef.v6i5.4405

Salifu, G. A. N. (2019b). The Political Economy Dynamics of Rural Household Income Diversification: Review of the international literature. Research in World Economy, 10(3), 10-34. https://doi.org/10.5430/rwe.v10n3p273

Stillman, S., McKenzie, D., \& Gibson, J. (2006). Migration and mental health: evidence from a natural experiment. BREAD Working Paper 123, Bureau for Research in Economic Analysis of Development, Washington, DC. https://doi.org/10.1596/1813-9450-4138

Woodruff, C., \& Zenteno, R. (2007). Migration networks and micro-enterprises in Mexico. Journal of Development Economics, 82(2), 509-528.

World Bank. (2008). Migration and Remittances Factbook, 2008. Washington, DC: World Bank. https://doi.org/10.1016/j.jdeveco.2006.03.006

World Bank. (2020). Brief: Food security and Covid-19.

Yang, D. (2008). International migration, remittances and household investment: evidence from Philippine migrants' exchange rate shocks. Economic Journal, 118(528), 591-630. https://doi.org/10.1111/j.1468-0297.2008.02134.x

Yang, D., \& Martinez, C. (2006). Remittances and poverty in migrants home areas: evidence from the Philippines, in: C. Ozden and M. Schiff (Eds.), International Migration, Remittances and the Brain Drain (pp. 81-121). Washington, DC: World Bank.

\section{Copyrights}

Copyright for this article is retained by the author(s), with first publication rights granted to the journal.

This is an open-access article distributed under the terms and conditions of the Creative Commons Attribution license (http://creativecommons.org/licenses/by/4.0/). 